\title{
Genetic Diversity Within Colletotrichum acutatum sensu Simmonds
}

\author{
Stanley Freeman, Dror Minz, Marcel Maymon, and Aida Zveibil
}

First, third, and fourth authors: Department of Plant Pathology, ARO, The Volcani Center, P.O. Box 6, Bet Dagan 50250; and second author: Institute of Soil, Water and Environmental Sciences, ARO, The Volcani Center, P.O. Box 6, Bet Dagan 50250, Israel. Accepted for publication 12 March 2001.

\begin{abstract}
Freeman, S., Minz, D., Maymon, M., and Zveibil, A. 2001. Genetic diversity within Colletotrichum acutatum sensu Simmonds. Phytopathology 91:586-592.

Isolates of Colletotrichum acutatum from several hosts were characterized by various molecular methods in comparison with morphological identification. Species-specific primer analysis was reliable for grouping C. acutatum isolates to their designated species. Arbitrarily primed polymerase chain reaction and A+T-rich DNA analyses identified four subgroups within C. acutatum. Subgroup I contained U.S. isolates from almond, apple, peach, and pecan, subgroup II contained isolates from anemone, olive, and strawberry, subgroup III contained isolates from almond (Israel) and strawberry (Spain), and subgroup IV contained a single
\end{abstract}

ABSTRACT

isolate from anemone (the Netherlands). Likewise, sequence analysis of the internal transcribed spacer (ITS) 2 region alone or the complete ITS (ITS 1-5.8S-ITS 2) region grouped the isolates into the same four subgroups. Percent similarity of the complete ITS region within each cluster ranged from 99.6 to $100.0,99.8$ to 100.0 , and $98.6 \%$ among subgroups I, II, and III, respectively. DNA sequence analysis of the ITS 2 region alone or the entire ITS 1-2 region was more informative than that of the ITS 1 region, which could only group the isolates into two main clusters. The molecular methods employed for studying genetic variation in populations of $C$. acutatum determined that this species is diverse, indicating that isolates within populations of each subgroup are not host specific.

Additional keywords: C. gloeosporioides, Glomerella, phylogeny.
The filamentous fungal plant pathogen Colletotrichum acutatum J. H. Simmonds, first described from Australia as a distinct species (26), is the cause of anthracnose diseases on many crops worldwide $(1-3,8,9,19,32)$. C. acutatum, reported as affecting 34 host genera in 22 families (30), has gained importance in recent years with many reports of new and recurring diseases caused by this species.

Identification and characterization of Colletotrichum spp. have relied solely on morphological criteria in the past. However, in recent years vegetative compatibility grouping (VCGs) and molecular techniques, coupled with traditional methodology have been used to elucidate the relationships within Colletotrichum (5,8-10,14, 23-25,27). A detailed study conducted in New Zealand on a diverse population of $C$. acutatum from fruit rots, lupin, and pine, reported that this species may be considered as a "group species", C. acutatum sensu lato (broad sense) (19). Within this collective group, four distinct $C$. acutatum sensu stricto (narrow sense) groups, including that first described by Simmonds were distinguished, based on sequence analysis of the rDNA D2 domain (18). Numerous reports have indicated that the teleomorph exists within the $C$. acutatum sensu Simmonds subgroup, termed group A, which may contribute to genetic diversity and heterogeneity $(16,18,19)$.

The primary objective of this study was to determine whether genetic diversity exists within the species $C$. acutatum Simmonds because to the best of our knowledge, a comprehensive molecular study has not been previously conducted for this subgroup. For this purpose, isolates conforming to subgroup $C$. acutatum Simmonds were compared by five molecular methods: (i) polymerase chain reaction (PCR) amplification using species-specific primers; (ii) arbitrarily primed (ap)-PCR amplification of genomic

Corresponding author: S. Freeman; E-mail address: freeman@ netvision.net.il

Publication no. P-2001-0412-01R

(C) 2001 The American Phytopathological Society
DNA; (iii) A+T-rich DNA patterns associated with the mitochondrial genome; (iv) restriction endonuclease digest analysis of PCR-amplified rDNA; and (v) sequencing of the complete rDNA internal transcribed spacer (ITS) region (ITS 1-5.8S-ITS 2). Phylogenetic analysis was performed to determine whether the ITS 1 region, ITS 2 region, and complete ITS 1-2 sequences provided more informative data than that previously published for the ITS 1 region alone (28).

\section{MATERIALS AND METHODS}

Fungal cultures and growth conditions. The monoconidial Colletotrichum spp. cultures used in this study included representative isolates of $C$. gloeosporioides from apple, avocado, and strawberry fruit, Israeli isolates of Colletotrichum from almond fruit, U.S. isolates of $C$. acutatum belonging to the pink subpopulation from almond fruit, U.S. isolates of $C$. acutatum from apple, peach, and pecan, and isolates of $C$. acutatum from anemone and strawberry from various origins (Table 1). The $C$. acutatum strains used in this study (all U.S. isolates and those from strawberry and anemone from various origins) represent the subgroup of $C$. acutatum sensu Simmonds (25), group A, according to morphological analyses based on conidial shape, mycelial growth, pigment in agar, and growth rate in culture, compared with other Colletotrichum spp. $(1,3,11,13,18)$. The $C$. acutatum isolates responsible for almond anthracnose in the United States were provided by B. Teviotdale, University of California, Davis. C. acutatum isolates (IMI345026 and IMI348494) from strawberry were provided by P. Cannon and A. Buddie, CABI Bioscience, Egham, England. All fungi were cultured in the dark on modified Mathur's medium (MS; $0.1 \%$ yeast extract, $0.1 \%$ bactopeptone, $1 \%$ sucrose, $0.25 \% \mathrm{MgSO}_{4} \cdot 7 \mathrm{H}_{2} \mathrm{O}, 0.27 \% \mathrm{KH}_{2} \mathrm{PO}_{4}$, and $2 \%$ agar supplemented with $25 \mathrm{mg}$ of ampicillin in 1 liter of sterile distilled water) (31). For DNA extraction, liquid cultures comprising $100 \mathrm{ml}$ of MS devoid of agar in 250-ml Erlenmeyer flasks were inoculated with five mycelial disks derived from colony margins. The cultures were agitated for 5 to 6 days on a rotary shaker at 
$150 \mathrm{rpm}$ and maintained at $25^{\circ} \mathrm{C}$. Twelve hours before harvesting mycelia, the cultures were fragmented by blending for $10 \mathrm{~s}$ at 24,000 rpm with a tissue homogenizer (Ultra-Turrax T25; Janke \& Kunkel, IKA-Labortechnik, Staufen, Germany) under sterile conditions and returned to the shaker. To avoid contamination, the homogenizer was washed in sterile water before blending each culture.

Isolation and purification of fungal DNA. Mycelia from $100 \mathrm{ml}$ of MS liquid cultures were collected by vacuum filtration and lyophilized until dry. DNA was extracted and purified as previously described (12). The DNA was dissolved in $0.5 \mathrm{ml}$ of Tris-EDTA buffer (10 mM Tris-HCl, $1 \mathrm{mM}$ EDTA at $\mathrm{pH}$ 8.0) to an approximate concentration of 200 to $500 \mu \mathrm{g} / \mathrm{ml}$ and diluted to a concentration of 10 to $100 \mathrm{ng} / \mu \mathrm{l}$ for PCR reactions.

PCR amplification. For ap-PCR, primers were derived from microsatellite or repeat sequences as follows: CAGCAGCAGCAGCAG (21), GTGGTGGTGGTGGTG, GACACGACACGACAC (17), and GACAGACAGACAGACA (33). In the text, these primers have been designated $(\mathrm{CAG})_{5},(\mathrm{GTG})_{5},(\mathrm{GACAC})_{3}$, and $(\mathrm{GACA})_{4}$, respectively. Universal PCR primers were used (ITS 1, TCCGTAGGTGAACCTGCGG and ITS 4, TCCTCCGCTTATTGATATGC) for amplification of the ITS 1 and ITS 2 regions between the small and large nuclear rDNA, including the 5.8S rDNA, as previously described (34). PCR primers for taxonspecific amplification included ITS 4 primer coupled with specific primers for $C$. acutatum (CaInt2) (GGGGAAGCCTCTCGCGG) and $C$. gloeosporioides (CgInt) (GGCCTCCCGCCTCCGGGCGG) (4). PCR reactions were performed in a total volume of $20 \mu \mathrm{l}$, containing 10 to $100 \mathrm{ng}$ of genomic DNA, $50 \mathrm{mM} \mathrm{KCl}$, $10 \mathrm{mM}$ Tris- $\mathrm{HCl}, 0.2 \mathrm{mM}$ each of dATP, dCTP, dGTP, and dTTP, $1.5 \mathrm{mM} \mathrm{MgCl}_{2}$, 1 unit of Taq DNA polymerase (Promega, Corp., Madison, WI), and $1 \mu \mathrm{M}$ primer. The reactions were incubated in a thermocycler (PTC-100; MJ Research, Watertown, MA) starting with $5 \mathrm{~min}$ of denaturation at $95^{\circ} \mathrm{C}$. For ap-PCR, this was followed by 30 cycles consisting of $30 \mathrm{~s}$ at $95^{\circ} \mathrm{C}, 30 \mathrm{~s}$ at either $60^{\circ} \mathrm{C}$ [for $(\mathrm{CAG})_{5}$ and $(\mathrm{GTG})_{5}$ ] or $48^{\circ} \mathrm{C}$ [for $(\mathrm{GACA})_{4}$ and $\left.(\mathrm{GACAC})_{3}\right]$ and $1.5 \mathrm{~min}$ at $72^{\circ} \mathrm{C}$. For rDNA amplification, denaturation was followed by 40 cycles consisting of $30 \mathrm{~s}$ at $95^{\circ} \mathrm{C}$, $30 \mathrm{~s}$ at $50^{\circ} \mathrm{C}$, and $1.5 \mathrm{~min}$ at $72^{\circ} \mathrm{C}$. Taxon-specific PCR reactions were performed under reaction conditions for primer $(\mathrm{CAG})_{5}$, with $0.5 \mu \mathrm{M}$ ITS 4 primer coupled with either $0.5 \mu \mathrm{M}$ primer $C a \mathrm{Int} 2$ for $C$. acutatum-specific detection or $0.5 \mu \mathrm{M}$ primer $C g \mathrm{Int}$ for $C$. gloeosporioides-specific detection. Amplification products were separated in agarose gels $(1.5 \%$, wt/vol; $15 \times 10 \mathrm{~cm})$ in Trisacetate-EDTA buffer (22) electrophoresed at $80 \mathrm{~V}$ for $2 \mathrm{~h}$. All PCR experiments were repeated at least four times with consistent results being achieved. Variation according to ap-PCR and A+Trich DNA analysis was not quantified, but diversity was interpreted according to overall banding patterns.

A+T-rich DNA analyses. A+T-rich DNA were analyzed by HaeIII digestion of total genomic DNA, which cleaves DNA at GGCC sites. HaeIII digests nuclear DNA to fragments mainly less than $2 \mathrm{~kb}$ in size, whereas A+T-rich sequences are cleaved less frequently $(12,15)$. A+T-rich DNA are partially associated with the mitochondrial genome although contaminating nuclear A+Trich DNA may also be present. Procedures used for HaeIII restriction enzyme digestion and agarose gel electrophoresis were similar to those previously described (12).

Restriction enzyme digestion of amplified rDNA and sequencing procedure. PCR-amplified rDNA products from representative isolates of Colletotrichum spp., using the primer pair ITS 1 and ITS 4 (34), resulted in a product of $\approx 560 \mathrm{bp}$, which was extracted from agarose gels with the Jetsorb kit (Genomed $\mathrm{GmbH}$, Germany). Recovered DNA was digested with restriction enzymes BamHI, HaeIII, HhaI, HindIII, MspI, PstI, RsaI, StuI, and TaqI, and separated on agarose gels. A DNA sequencing kit (Big Dye Terminator DNA; Perkin-Elmer Inc., Branchburg, NJ) was used for determining sequence of the ITS 1-2 regions (34).
The sequence was determined with a DNA sequencer (ABI Prism 377; Applied Biosystem Inc., Foster City, CA) and was performed at the sequencing unit of the Hebrew University of Jerusalem, Israel.

Phylogenetic analysis. Analyses of ITS sequences were carried out using the program package ARB (University of Munich, Germany) (29). Alignment of sequences was performed with the implemented ARB-automated alignment tool and alignments were refined manually. Phylogenetic analyses were performed by applying ARB parsimony, distance matrix, and maximum-likelihood methods. To determine the robustness of phylogenetic trees, analyses were performed both on the original data set and on a data set from which highly variable positions were removed by use of a $50 \%$ conservation filter for the members of Colletotrichum spp., to reduce potential tree artifacts that may result from multiple base changes. Analysis was conducted on the ITS 1 and 2 sequences of DNA from representative isolates of C. gloeosporioides from U.S. apple (APL-7), Israel avocado (AVO-37-4B), and U.S. strawberry (CG-231-1), isolates of C. acutatum from U.S. apple (APL-2), U.S. peach (PCH-8), U.S. pecan (PCN-5), U.S. almond (ALM-US-4A), Australia anemone (IMI-223210), Netherlands anemone (ANE-NL-12A), Israel anemone (ANEHV83C), U.S. strawberry (STR-3), Israel strawberry (TUT-5954), France strawberry (IMI-348494), Spain strawberry (IMI-345026), Israel Colletotrichum isolate from almond (ALM-KSH-10), and a number of Colletotrichum sequences retrieved from GenBank (Table 2). The $C$. acutatum strawberry isolates from France and Spain represent two separate rDNA groups (5). Complete ITS 1-2 sequences of the isolates were submitted to GenBank, with accession numbers appearing in Table 2.

\section{RESULTS}

Species-specific primer analysis. DNA from 13 U.S. pink isolates of $C$. acutatum from almond fruit, 13 U.S. isolates of $C$. acutatum from apple, peach, pecan, and strawberry, three isolates of $C$. acutatum from anemone from various origins, 139 Israeli isolates of $C$. acutatum from strawberry, 57 Israeli Colletotrichum almond isolates, and three representative $C$. gloeosporioides isolates from apple (APL-7), avocado (AVO-37-4B), and strawberry (CG-231-1), were PCR amplified with species-specific

TABLE 1. Isolates of Colletotrichum spp. used in this study

\begin{tabular}{llll}
\hline Species & Isolate & Origin & Host plant \\
\hline C. gloeosporioides & APL-7 & North Carolina, U.S. & Apple \\
C. gloeosporioides $^{\text {AVO-37-4B }}$ & AV & Israel & Avocado \\
C. gloeosporioides & CG 231-1 & Florida, U.S. & Strawberry \\
C. acutatum & APL-2 & South Carolina, U.S. & Apple \\
C. acutatum & PCH-8 & South Carolina, U.S. & Peach \\
C. acutatum & PCN-5 & Alabama, U.S. & Pecan \\
C. acutatum & ALM-US-4A & California, U.S. & Almond \\
Colletotrichum & ALM-KSH-10 & Israel & Almond \\
C. acutatum & IMI 223120 & Australia & Anemone \\
C. acutatum & ANE-NL-12A & Netherlands & Anemone \\
C. acutatum & ANE-HV83C & Israel & Anemone \\
C. acutatum & STR-3 & South Carolina, U.S. & Strawberry \\
C. acutatum & TUT-5954 & Israel & Strawberry \\
C. acutatum & IMI 345026 & Spain & Strawberry \\
C. acutatum & IMI 348494 & France & Strawberry \\
\hline
\end{tabular}

a Other representative $C$. acutatum isolates were: apple (APL-5) from Arkansas, U.S., apple (APL-12 and APL-13) from North Carolina, U.S.; peach (PCH-1, SF-2, SF-3, and SF-7) from South Carolina, U.S.; pecan (PCN-6 and PCN-8) from Alabama, U.S.; and strawberry (STR-5) from North Carolina, U.S.

${ }^{\mathrm{b}}$ Other representative U.S. almond isolates of the pink subpopulation were ALM-US-2B, -3B, -5A, -5B, -6A, -7B, -8A, -8B, -10A, -10B, -11A, and $-12 \mathrm{~A}$.

c Other almond representatives included 55 clonal isolates from Israel (9).

${ }^{\mathrm{d}}$ Other strawberry representatives included 138 clonal isolates from Israel (8). 
primers. Isolates within each population reacted identically and amplified the same size product. Representative isolates were then chosen for presentation of data.

DNA from representative isolates of $C$. acutatum from U.S. apple (APL-2), U.S. peach (PCH-8), U.S. pecan (PCN-5), U.S. almond (ALM-US-4A), Australia anemone (IMI-223210), Netherlands anemone (ANE-NL-12A), Israel anemone (ANEHV83C), U.S. strawberry (STR-3), Israel strawberry (TUT-5954), Israel Colletotrichum isolate from almond (ALM-KSH-10), and C. gloeosporioides from U.S. apple (APL-7), Israel avocado (AVO-37-4B), and U.S. strawberry (CG-231-1) were PCR-amplified with species-specific primers (Fig. 1). The CaInt2-specific primer for $C$. acutatum in conjunction with the ITS 4 primer amplified a 490-bp fragment from genomic DNA of the $C$. acutatum isolates as well as that of the Israel Colletotrichum isolate from almond (ALM-KSH-10), but not from DNA of the $C$. gloeosporioides apple, avocado, and strawberry isolates (Fig. 1A). In contrast, DNAs of $C$. acutatum and Israeli almond isolates were not amplified by $C$. gloeosporioides-specific $C g$ Int primer in conjunction with the ITS 4 primer, whereas a 450-bp fragment was amplified from DNA of the representative C. gloeosporioides isolates alone (Fig. 1B). Therefore, the species-specific primers differentiated strains at the species level but not at the subspecies level.

ap-PCR analysis. Genomic DNA from all isolates included in the species-specific analysis was amplified by ap-PCR using primers $(\mathrm{GTG})_{5},(\mathrm{GACAC})_{3},(\mathrm{CAG})_{5}$, and $(\mathrm{GACA})_{4}$ (Figs. 2 and 3). Amplified products from isolates of U.S. C. acutatum from almond, Israeli Colletotrichum from almond, and Israeli $C$. acutatum from strawberry were identical among isolates within each population, indicating clonality, whereas heterogeneity was observed among the $C$. gloeosporioides populations. The same representative isolates that were used in the species-specific analysis were also used for ap-PCR. Four subpopulations of $C$. acutatum were identified by ap-PCR using primers $(\mathrm{GTG})_{5}$ and $(\text { GACAC })_{3}$, (Fig. $2 \mathrm{~A}$ and $\left.\mathrm{B}\right)$ and $(\mathrm{CAG})_{5}$ and $(\mathrm{GACA})_{4}$ (Fig. $3 \mathrm{~A}$ and B). Subgroup I contained U.S. isolates of C. acutatum from almond, apple, peach, and pecan, whereas subgroup II included isolates of $C$. acutatum from anemone (Australia and Israel) and strawberry (United States and Israel). Unique band patterns were observed for the Israeli Colletotrichum almond population (subgroup III) and that of the anemone isolate NL-12A from the Netherlands (subgroup IV).

A+T-rich DNA analysis. A+T-rich DNA were analyzed by observing HaeIII digestions of genomic DNA from the representative isolates used for species-specific and ap-PCR analyses. Results obtained by this method corroborated those observed by ap-PCR. The same four subpopulations of $C$. acutatum were identified by A+T-rich DNA analysis (Fig. 4), subgroup I containing U.S. isolates of $C$. acutatum from almond, apple, peach, and pecan, and subgroup II including isolates of $C$. acutatum from anemone (Australia and Israel) and strawberry (United States and Israel). Similar to ap-PCR, A+T-rich DNA analysis showed that the Israeli Colletotrichum almond population and that of the anemone isolate NL-12A from the Netherlands were unique. DNA band patterns from each representative isolate of $C$. gloeosporioides were also unique in inter- and intraspecies comparisons (Fig. 4).

Polymorphism of rDNA ITS 1-2 restriction digests. Restriction endonuclease digest patterns of PCR-amplified rDNA ITS 1-2 regions were compared for the representative $C$. gloeosporioides and $C$. acutatum isolates. Enzyme RsaI distinguished between the representative isolates of Colletotrichum spp. (Fig. 5) by recognizing unique restriction sites, in contrast to enzymes BamHI, HaeIII, HhaI, HindIII, MspI, PstI, StuI, and TaqI, which did not possess unique sites among the different species. RsaI cleaved the amplified fragment of the $C$. gloeosporioides isolates at a unique site. The amplified fragment of subgroup I isolates of

TABLE 2. Internal transcribed spacer (ITS) 1 and 2 sequences of Colletotrichum spp. isolates used in this study

\begin{tabular}{|c|c|c|c|c|}
\hline Species & Isolate & Host & EMBL accession & ITS region \\
\hline C. lindemuthianum & CLD2 ${ }^{\mathrm{a}}$ & Phaseolus vulgaris & Z 32987 & 1 \\
\hline C. orbiculare & $172.59^{a}$ & Cucumis sativus & Z 33379 & 1 \\
\hline C. graminicola & $\mathrm{DR} 1^{\mathrm{b}}$ & Роа аппиа & AF 059676 & 2 \\
\hline C. gloeosporioides & $\mathrm{CG} 231^{\mathrm{c}}$ & Fragaria $\times$ ananassa & AF 272780 & $1-2$ \\
\hline C. gloeosporioides & AVO-37-4B ${ }^{c}$ & Persea americana & AF 207792 & $1-2$ \\
\hline C. gloeosporioides & APL $7^{c}$ & Malus domestica & AF 272779 & $1-2$ \\
\hline C. acutatum & IMI $348494^{c}$ & Fragaria $\times$ ananassa & AF 272785 & $1-2$ \\
\hline C. acutatum & GL-118-9411 ${ }^{\mathrm{d}}$ & Olea europaea & AF 081292 & 2 \\
\hline C. acutatum & TUT 5954c & Fragaria $\times$ ananassa & AF 207794 & $1-2$ \\
\hline C. acutatum & $397^{\mathrm{a}}$ & Fragaria $\times$ ananassa & Z 32915 & 1 \\
\hline C. acutatum & $\mathrm{PCN} 5^{\mathrm{c}}$ & Carya illinoensis & AF 272786 & $1-2$ \\
\hline C. acutatum & $\mathrm{PCH} 8^{\mathrm{c}}$ & Prunus persica & AF 272788 & $1-2$ \\
\hline C. acutatum & CECT-20120 ${ }^{\mathrm{d}}$ & Fragaria $\times$ ananassa & AF 090853 & 2 \\
\hline C. acutatum & ANE-HV83C ${ }^{c}$ & Anemone coronaria & AF 272782 & $1-2$ \\
\hline C. acutatum & STR $3^{\mathrm{c}}$ & Fragaria $\times$ ananassa & AF 272784 & $1-2$ \\
\hline C. acutatum & ALM-US-4c & Prunus dulcis & AF 207793 & $1-2$ \\
\hline C. fructigenum & $4885^{\mathrm{a}}$ & Acmena smithii & Z 32907 & 2 \\
\hline C. acutatum & $493 / \mathrm{BOX} 88^{\mathrm{a}}$ & Fragaria $\times$ ananassa & Z 32916 & 1 \\
\hline C. acutatum & IMI $223120^{c}$ & Anemone coronaria & AF 272783 & $1-2$ \\
\hline C. acutatum & $179^{\mathrm{e}}$ & Fragaria $\times$ ananassa & Z 32913 & 1 \\
\hline C. acutatum & APL $2^{c}$ & Malus domestica & AF 272787 & $1-2$ \\
\hline C. acutatum & ANE-NL12A ${ }^{c}$ & Anemone coronaria & AF 272781 & $1-2$ \\
\hline C. acutatum & $602 / 91.326^{\mathrm{a}}$ & Phormium spp. & Z 32924 & 1 \\
\hline C. acutatum & IMI $345026^{\mathrm{c}}$ & Fragaria $\times$ ananassa & AF 272789 & $1-2$ \\
\hline Colletotrichum & ALM-KSH-10 & Prunus dulcis & AF 207791 & $1-2$ \\
\hline C. acutatum & $615 / 91.414^{\mathrm{a}}$ & Fragaria $\times$ ananassa & Z 32925 & 1 \\
\hline C. acutatum & $534 / 90.368^{\mathrm{a}}$ & Ceanothus spp. & Z 32918 & 1 \\
\hline C. acutatum & $616 / 91.414^{\mathrm{a}}$ & Fragaria $\times$ ananassa & Z 32926 & 1 \\
\hline
\end{tabular}

a Isolates sequenced by Sreenivasaprasad et al. (28).

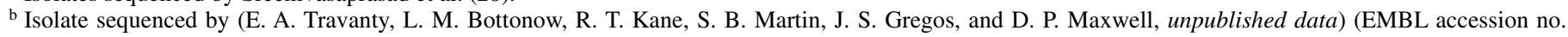
AF 059676).

${ }^{\mathrm{c}}$ Isolates sequenced by S. Freeman, D. Minz, M. Maymon, and A. Zveibil.

d Isolates sequenced by Martín and García-Figueres (20).

e Isolate sequenced by Sreenivasaprasad et al. (28) (EMBL accession no. Z 32913). 
C. acutatum were also cleaved by RsaI, whereas subgroup II isolates, including the Israeli Colletotrichum almond population and that of the anemone isolate NL-12A from the Netherlands, remained uncut (Fig. 5).

Sequence and phylogenetic analysis. Sequence analyses were conducted on $C$. acutatum isolates from U.S. apple (APL-2), U.S. peach (PCH-8), U.S. pecan (PCN-5), U.S. almond (ALM-US4A), Australia anemone (IMI-223210), Netherlands anemone (ANE-NL-12A), Israel anemone (ANE-HV83C), U.S. strawberry (STR-3), Israel strawberry (TUT-5954), and Israel Colletotrichum isolate from almond (ALM-KSH-10). Two additional C. acutatum representatives from strawberry, isolate IMI-348494 from France and isolate IMI-345026 from Spain, were sequenced and data are included in this study. Reference $C$. gloeosporioides isolates from U.S. apple (APL-7), Israel avocado (AVO-37-4B), and U.S. strawberry (CG-231-1) were sequenced.

Phylogenetic analysis was performed using both ITS 1 sequences (Fig. 6), ITS 1-2 and ITS 2 fragments (Table 3; Fig. 7). Comparative analysis of ITS 1 sequences produced a phylogenetic tree (Fig. 6) that supported the previous analysis published by Sreenivasaprasad et al. (28). This analysis confirmed that 20 of the $C$. acutatum isolates, 11 from this study, were grouped separately from reference cultures of the species $C$. gloeosporioides, $C$. graminicola, $C$. orbiculare, and $C$. lindemuthianum.

Analysis of sequences of ITS 1-2 and ITS 2 fragments supported the phylogeny inferred from the ITS 1 tree, however ITS 2 region showed a greater interspecies divergence than that of ITS 1. Analysis was performed on the sequences of 15 isolates mentioned previously, as well as those available in GenBank $(C$. acutatum isolate IMI345028 or CECT 20120 from strawberry [EMBL accession no. AF 090853], C. acutatum isolate GLOCOL01 or GL-118-9411 from olive [EMBL accession no. AF 081292],

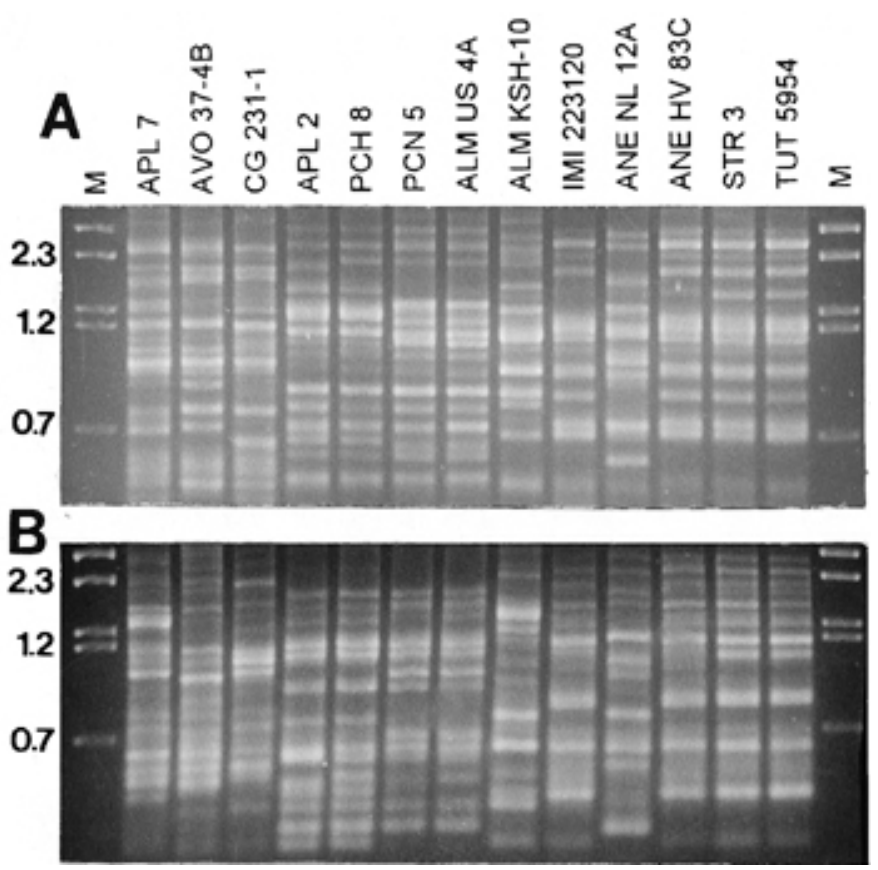

Fig. 2. Band patterns of arbitrarily primed polymerase chain reaction-amplified genomic DNA of Colletotrichum gloeosporioides isolates from U.S. apple (APL 7), Israel avocado (AVO 37-4B), and U.S. strawberry (CG 2311), and from C. acutatum isolates from U.S. apple (APL 2), U.S. peach (PCH 8), U.S. pecan (PCN 5), U.S. almond (ALM US 4A), Israel Colletotrichum isolate from almond (ALM KSH-10), Australia anemone (IMI 223120), the Netherlands anemone (ANE NL-12A), Israel anemone (ANE HV 83C), U.S. strawberry (STR 3), and Israel strawberry (TUT 5954) using primers A, $(\mathrm{GTG})_{5}$ and $\mathbf{B},(\mathrm{GACAC})_{3}$. Lane $\mathrm{M}, \mathrm{DNA}$ markers in kilobases.

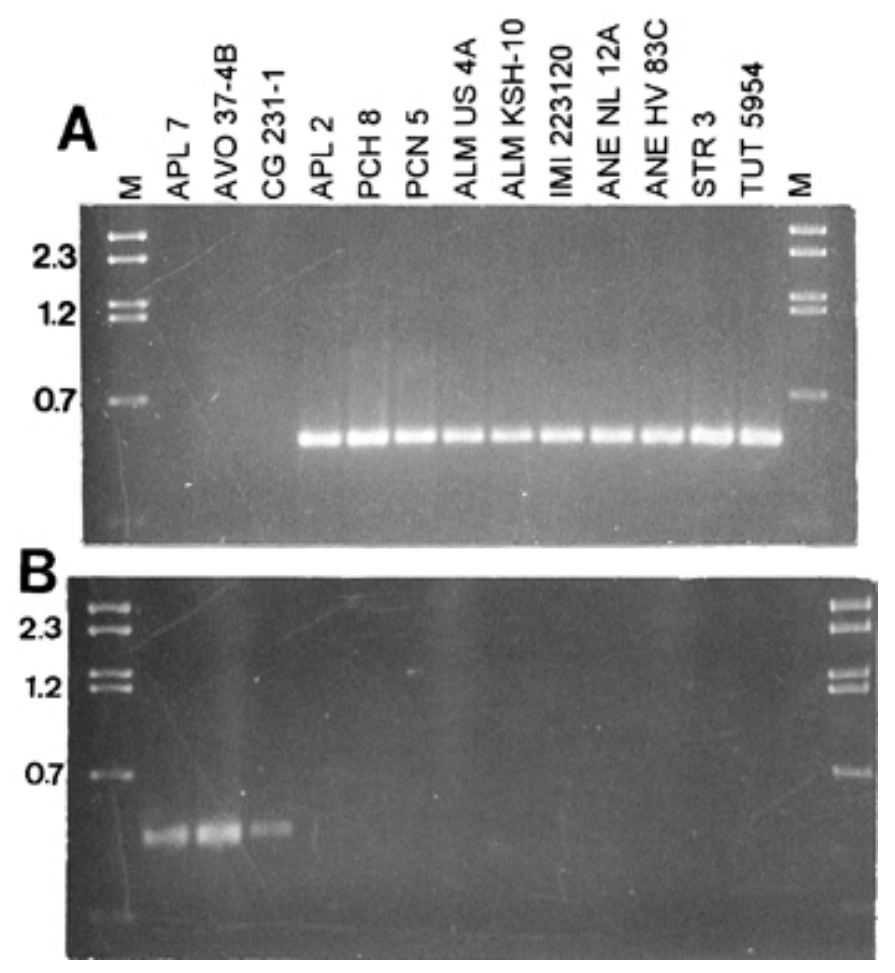

Fig. 1. Taxon-specific A, Colletotrichum acutatum and B, C. gloeosporioides amplification products of genomic DNA from C. gloeosporioides isolates from U.S. apple (APL 7), Israel avocado (AVO 37-4B), and U.S. strawberry (CG 231-1), and from C. acutatum isolates from U.S. apple (APL 2), U.S. peach (PCH 8), U.S. pecan (PCN 5), U.S. almond (ALM US 4A), Israel Colletotrichum isolate from almond (ALM KSH-10), Australia anemone (IMI 223120), the Netherlands anemone (ANE NL-12A), Israel anemone (ANE HV 83C), U.S. strawberry (STR 3), and Israel strawberry (TUT 5954). Lane M, DNA markers in kilobases.

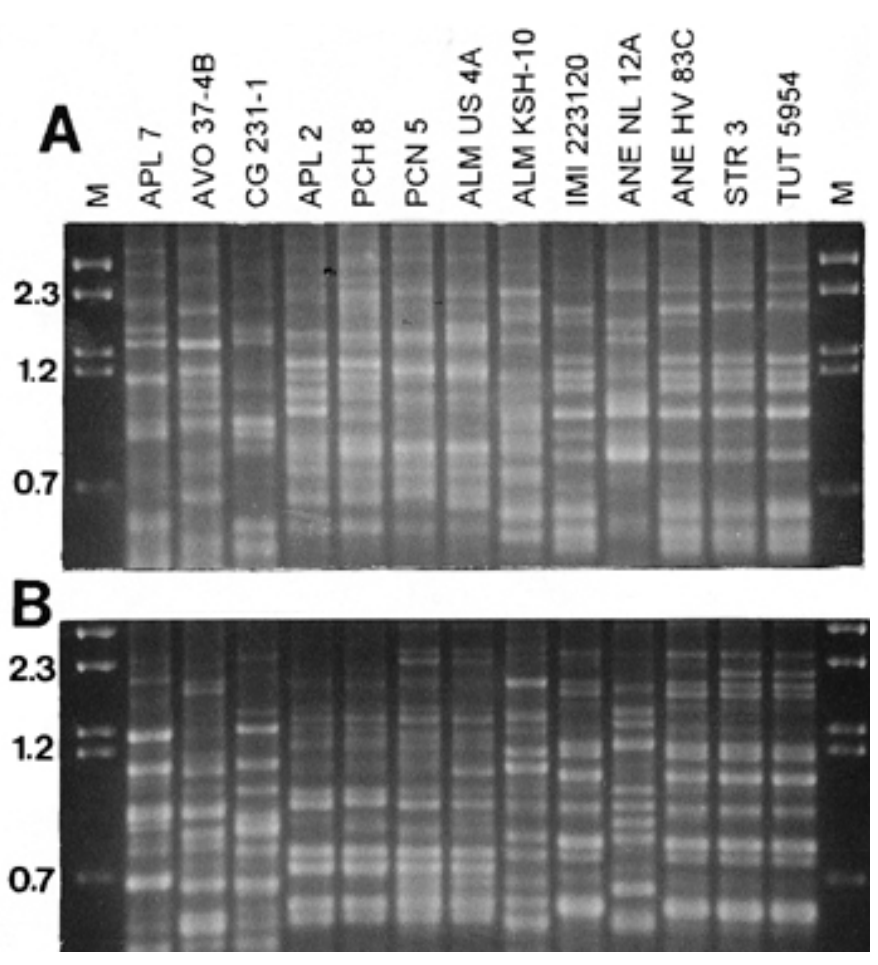

Fig. 3. Band patterns of arbitrarily primed polymerase chain reactionamplified genomic DNA of Colletotrichum gloeosporioides isolates from U.S. apple (APL 7), Israel avocado (AVO 37-4B), and U.S. strawberry (CG 231-1), and from C. acutatum isolates from U.S. apple (APL 2), U.S. peach (PCH 8), U.S. pecan (PCN 5), U.S. almond (ALM US 4A), Israel Colletotrichum isolate from almond (ALM KSH-10), Australia anemone (IMI 223120), the Netherlands anemone (ANE NL-12A), Israel anemone (ANE HV 83C), U.S. strawberry (STR 3), and Israel strawberry (TUT 5954) using primers $\mathbf{A},(\mathrm{CAG})_{5}$ and $\mathbf{B},(\mathrm{GACA})_{4}$. Lane $\mathrm{M}, \mathrm{DNA}$ markers in kilobases. 
and $C$. graminicola isolate DR1 from turfgrass [EMBL accession no. AF 059676]). It should be noted that sequence comparisons conducted on submissions to GenBank may contain errors because sequencing was not confirmed independently in this study. Based on ITS 1 sequence alone, the $C$. acutatum isolates clustered within two groups (Fig. 6). However, based on sequence analysis of the ITS 1 and 2 regions (Table 3 ) and ITS 2 region alone (Fig. 7), four C. acutatum clusters were revealed that corresponded to the four subgroups previously identified by ap-PCR and A+T-rich DNA analysis. Subgroup I, comprised mainly of U.S. isolates from the various fruits, shared 99.6 to $100 \%$ identity. Subgroup II,

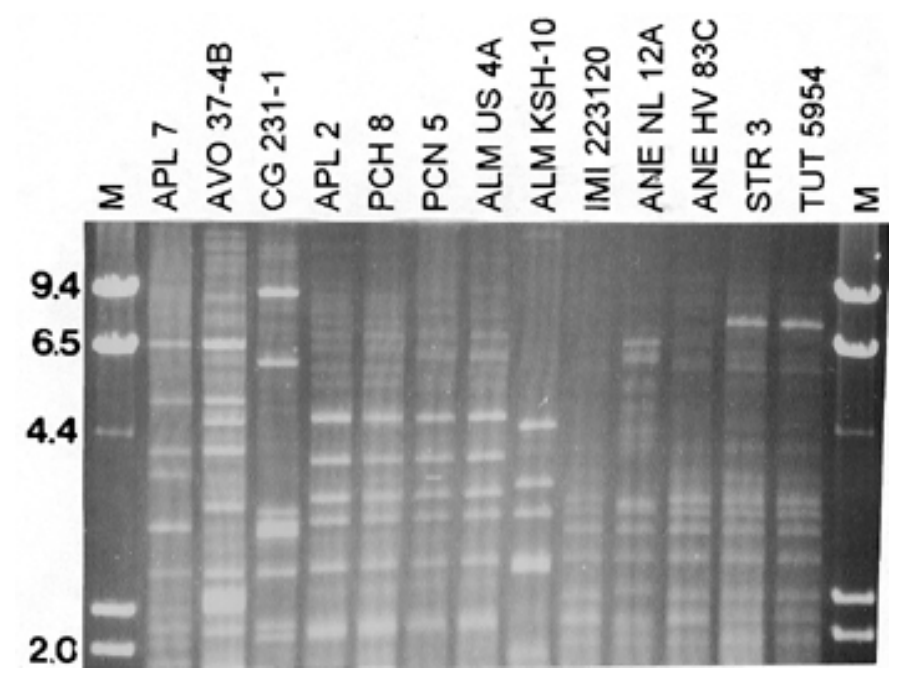

Fig. 4. Band patterns of genomic DNA from Colletotrichum gloeosporioides isolates from U.S. apple (APL 7), Israel avocado (AVO 37-4B), and U.S. strawberry (CG 231-1), and from C. acutatum isolates from U.S. apple (APL 2), U.S. peach (PCH 8), U.S. pecan (PCN 5), U.S. almond (ALM US 4A), Israel Colletotrichum isolate from almond (ALM KSH-10), Australia anemone (IMI 223120), the Netherlands anemone (ANE NL-12A), Israel anemone (ANE HV 83C), U.S. strawberry (STR 3), and Israel strawberry (TUT 5954) digested with HaeIII for A+T-rich DNA analysis. DNA were electrophoresed until the major $\mathrm{G}+\mathrm{C}$-rich fragments were eluted from the gel. Lane M, DNA markers in kilobases.

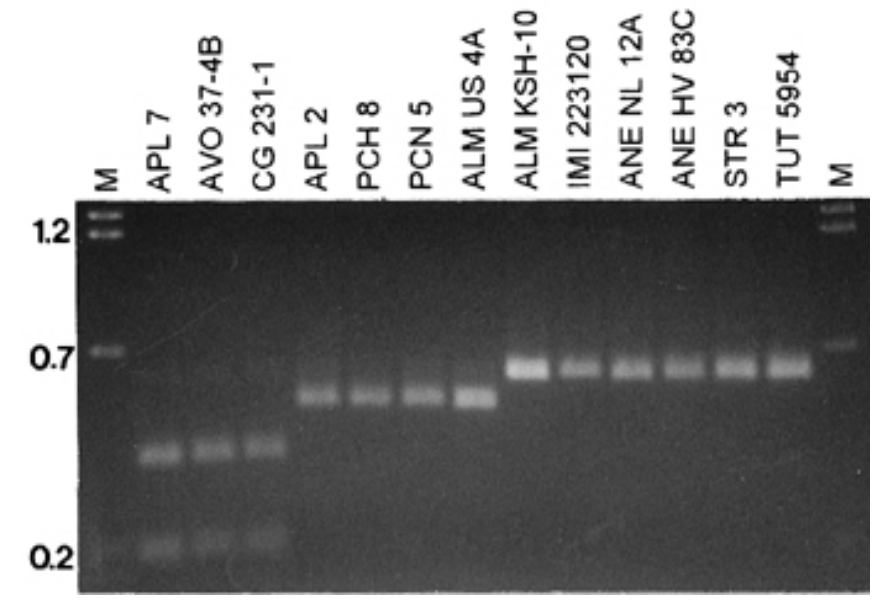

Fig. 5. RsaI restriction enzyme digests of polymerase chain reaction-amplified ribosomal DNA of the entire internal transcribed spacer (ITS) region (ITS 15.8S-ITS 2) from Colletotrichum gloeosporioides isolates from U.S. apple (APL 7), Israel avocado (AVO 37-4B), and U.S. strawberry (CG 231-1), and from C. acutatum isolates from U.S. apple (APL 2), U.S. peach (PCH 8), U.S. pecan (PCN 5), U.S. almond (ALM US 4A), Israel Colletotrichum isolate from almond (ALM KSH-10), Australia anemone (IMI 223120), the Netherlands anemone (ANE NL-12A), Israel anemone (ANE HV 83C), U.S. strawberry (STR 3), and Israel strawberry (TUT 5954). Lane M, DNA markers in kilobases. comprising mainly of anemone, olive, and strawberry isolates, shared 99.8 to $100 \%$ identity (Table 3 ). Percent similarity between isolates of subgroups I and II ranged from 98.4 to $98.9 \%$ (Table 3). Subgroup III, associated with $C$. acutatum, included the population of Colletotrichum from almond in Israel represented by isolate ALM-KSH-10 and C. acutatum strawberry isolate IMI 345026 from Spain (Fig. 7). The C. acutatum anemone isolate NL-12A from the Netherlands, representing subgroup IV, was more closely associated to subgroup I and II than the isolates of subgroup III (Table 3). Percent similarity of the C. acutatum populations to those of $C$. gloeosporioides ranged from 92.7 and 93.5\%. C. graminicola isolate DR1 was more closely related to the $C$. gloeosporioides cluster (95.7 to $96.2 \%$ similarity) than to that of C. acutatum (92.3 to $93.6 \%$ similarity) (Table 3 ).

\section{DISCUSSION}

The main objective of this study was to determine whether the various molecular methods used were able to identify variability among populations of $C$. acutatum Simmonds in particular, and whether genetic diversity was evident within populations of this subspecies. Each molecular method was evaluated for the ability to assess the identity of isolates within $C$. acutatum Simmonds. The species-specific primer analysis based on ITS1 sequences was reliable for differentiating between isolates from the two species complexes, $C$. gloeosporioides and $C$. acutatum, whereas ap-PCR, $\mathrm{A}+\mathrm{T}-\mathrm{rich}$ and rDNA restriction fragment length polymorphisms (RFLPs), and ITS 1-2 sequence analyses were useful for determining subpopulation diversity within C. acutatum.

According to ap-PCR and A+T-rich DNA analyses, four separate subgroups were distinguished within Simmonds: subgroup I, which included isolates from various U.S. fruit sources

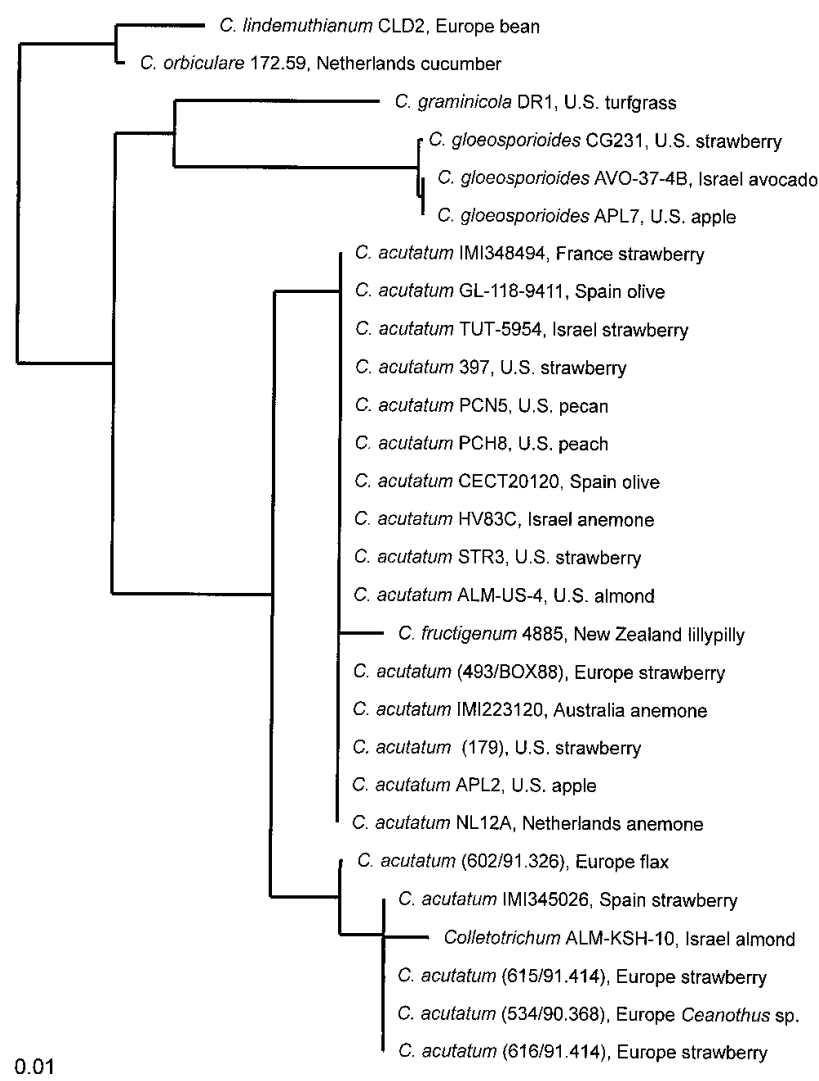

Fig. 6. Internal transcribed spacer 1-based phylogenetic tree of Colletotrichum spp. isolates and published sequences. The tree was produced using the neighbor-joining algorithm, and orders of branching was similar in all tree construction approaches used. Scale bar indicates estimated $1 \%$ sequence divergence. 
and subgroup II, which included isolates from anemone, olive, and strawberry. rDNA restriction digest analysis provided similar results to ap-PCR and A+T-rich DNA analyses, grouping isolates of different $C$. acutatum populations into the same subgroups I and II, indicating the reliability and independence of each of these techniques separately.

Due to its high rate of genetic variation, ITS 1 region within the rDNA gene cluster has been considered suitable for species delimitation (28). In this study, the complete rDNA region, encompassing the ITS 1-2 regions and the 5.8S rDNA gene, was used for DNA sequence analysis. Although analysis of sequences of the ITS 1-2 fragment supported the phylogeny inferred from the ITS 1 tree, the ITS 2 region showed a greater interspecies divergence than that of ITS 1 alone (Figs. 6 and 7). When the analysis was performed on 14 C. acutatum isolates using ITS 1 sequence alone, a single group was identified, whereas analysis of the ITS 1-2 region enabled identification of two main subgroups, I and II, as well as two additional subgroups, III and IV. Four subgroups of fruit-rotting $C$. acutatum isolates were characterized by Lardner et al. (19) using random amplified polymorphic DNA-PCR and morphological criteria. Although ITS sequence analysis was not used in that study, it may be plausible to assume that the four subgroups characterized in our study may be comparable with those identified in New Zealand. Previously, Buddie et al. (5) identified three separate rDNA RFLP groups (RGs) of $C$. acutatum from strawberry. In that study, isolate IMI 348494 from France was included within RG4, whereas isolate IMI 345026 from Spain within RG3. According to the ITS 1-2 sequence analysis conducted here, strawberry isolate IMI 348494 from France was placed with other strawberry isolates (from various sources) in subgroup II, whereas strawberry isolate IMI 345026 from Spain was grouped separately within subgroup III. Therefore, the ITS 1-2 sequence analysis conducted in this study corresponded to the RG analysis reported (5). Our findings in this study are supported by the statement by Sherriff et al. (24), whereby the ITS 2 region should provide opportunities for more rapid progress in taxonomic studies of the genus Colletotrichum and may be as valuable, if not more informative, than the ITS 1 region alone. Therefore, future molecular phylogeny studies of Colletotrichum spp. should consider ITS 2 region for additional subspecies delimitation, as demonstrated in this study.

A number of reports from New Zealand and the United States have recorded the presence of the teleomorph in $C$. acutatum sensu Simmonds $(16,18,19)$. Therefore, it may be assumed that existence of the teleomorph may contribute to the genetic diversity observed within and between each subgroup as demonstrated in this work. Moreover, a high level of VCG diversity was discovered among $C$. acutatum sensu Simmonds isolates from apple (6), indicating heterogeneity. Alternatively, clonal populations have been characterized within these subgroups, such as the pathogen causing strawberry anthracnose in Israel and the pink subpopulation affecting almond in California, indicating that little or no variation may occur $(7,8,10)$.

In summary, ap-PCR and A+T-rich DNA analyses supported the ITS 2 sequence analysis, which grouped each population of $C$. acutatum sensu Simmonds into four subgroups. Furthermore, sequence analysis of ITS 2 region alone provided additional infor-

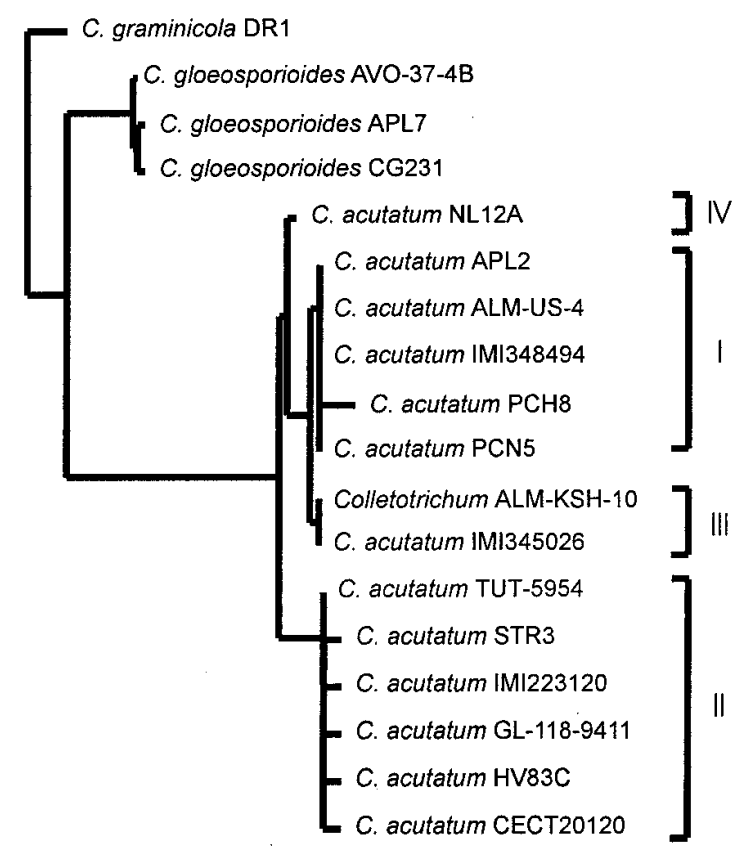

0.1

Fig. 7. Internal transcribed spacer 2-based phylogenetic tree of Colletotrichum spp. isolates and published sequences. The tree was produced using the neighbor-joining algorithm, and orders of branching was similar in all tree construction approaches used. Scale bar indicates estimated $1 \%$ sequence divergence.

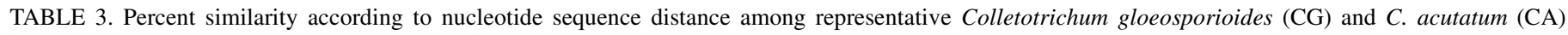
isolates, was based on the entire internal transcribed spacer (ITS) region (ITS 1-5.8S-ITS 2) ${ }^{\mathrm{a}}$

\begin{tabular}{|c|c|c|c|c|c|c|c|c|c|c|c|c|c|c|c|c|c|c|}
\hline Isolate code & 1 & 2 & 3 & 4 & 5 & 6 & 7 & 8 & 9 & 10 & 11 & 12 & 13 & 14 & 15 & 16 & 17 & 18 \\
\hline 1. CG AVO-37-4B & 100 & & $\ldots$ & $\ldots$ & $\ldots$ & $\ldots$ & $\ldots$ & $\ldots$ & $\ldots$ & $\ldots$ & $\ldots$ & $\ldots$ & $\ldots$ & $\ldots$ & $\ldots$ & $\ldots$ & $\ldots$ & $\ldots$ \\
\hline 2. CA TUT-5954 & 93.2 & 100 & $\ldots$ & $\ldots$ & $\ldots$ & $\ldots$ & $\ldots$ & $\ldots$ & $\ldots$ & $\ldots$ & $\ldots$ & $\ldots$ & $\ldots$ & $\ldots$ & $\ldots$ & $\ldots$ & $\ldots$ & $\ldots$ \\
\hline 3. CA US-ALM4 & 93.2 & 98.9 & 100 & $\ldots$ & $\ldots$ & $\ldots$ & $\ldots$ & $\ldots$ & $\ldots$ & $\ldots$ & $\ldots$ & $\ldots$ & $\ldots$ & $\ldots$ & $\ldots$ & $\ldots$ & $\ldots$ & $\ldots$ \\
\hline 4. C ALM-KSH & 92.7 & 97.7 & 98.4 & 100 & $\ldots$ & $\ldots$ & $\ldots$ & $\ldots$ & $\ldots$ & $\ldots$ & $\ldots$ & $\ldots$ & $\ldots$ & $\ldots$ & $\ldots$ & $\ldots$ & $\ldots$ & $\ldots$ \\
\hline 5. CGR DR1 & 95.7 & 93.3 & 93.3 & 92.3 & 100 & $\ldots$ & $\ldots$ & $\ldots$ & $\ldots$ & $\ldots$ & $\ldots$ & $\ldots$ & $\ldots$ & $\ldots$ & $\ldots$ & $\ldots$ & $\ldots$ & $\ldots$ \\
\hline 6. CA APL2 & 93.0 & 98.6 & 99.8 & 98.2 & 93.1 & 100 & $\ldots$ & $\ldots$ & $\ldots$ & $\ldots$ & $\ldots$ & $\ldots$ & $\ldots$ & $\ldots$ & $\ldots$ & $\ldots$ & $\ldots$ & $\ldots$ \\
\hline 7. CG APL7 & 100 & 93.2 & 93.2 & 92.7 & 95.7 & 93.0 & 100 & $\ldots$ & $\ldots$ & $\ldots$ & $\ldots$ & $\ldots$ & $\ldots$ & $\ldots$ & $\ldots$ & $\ldots$ & $\ldots$ & $\ldots$ \\
\hline 8. CG 231 & 100 & 93.1 & 93.1 & 92.6 & 96.2 & 92.9 & 100 & 100 & $\ldots$ & $\ldots$ & $\ldots$ & $\ldots$ & $\ldots$ & $\ldots$ & $\ldots$ & $\cdots$ & $\ldots$ & $\ldots$ \\
\hline 9. CA HV83C & 93.0 & 99.8 & 98.6 & 97.5 & 93.1 & 98.4 & 93.0 & 92.9 & 100 & $\ldots$ & $\ldots$ & $\ldots$ & $\ldots$ & $\ldots$ & $\ldots$ & $\ldots$ & $\ldots$ & $\ldots$ \\
\hline 10. CA PCH8 & 92.7 & 98.4 & 99.6 & 97.9 & 92.8 & 99.3 & 92.7 & 92.6 & 98.2 & 100 & $\ldots$ & $\ldots$ & $\ldots$ & $\ldots$ & $\ldots$ & $\ldots$ & $\ldots$ & $\ldots$ \\
\hline 11. CA IMI223120 & 93.0 & 99.8 & 98.6 & 97.5 & 93.1 & 98.4 & 93.0 & 92.9 & 99.6 & 98.2 & 100 & $\ldots$ & $\ldots$ & $\ldots$ & $\ldots$ & $\ldots$ & $\ldots$ & $\ldots$ \\
\hline 12. CA NL12 & 93.5 & 99.3 & 99.6 & 97.9 & 93.6 & 99.3 & 93.5 & 93.4 & 99.1 & 99.1 & 99.1 & 100 & $\ldots$ & $\ldots$ & $\ldots$ & $\ldots$ & $\ldots$ & $\ldots$ \\
\hline 13. CA PCN5 & 93.2 & 98.9 & 100 & 98.4 & 93.3 & 99.8 & 93.2 & 93.1 & 98.6 & 99.6 & 98.6 & 99.6 & 100 & $\ldots$ & $\ldots$ & $\ldots$ & $\ldots$ & $\ldots$ \\
\hline 14. CA STR3 & 93.0 & 99.8 & 98.6 & 97.5 & 93.1 & 98.4 & 93.0 & 92.9 & 99.6 & 98.2 & 99.6 & 99.1 & 98.6 & 100 & $\ldots$ & $\ldots$ & $\ldots$ & $\ldots$ \\
\hline 15. CA IMI345026 & 93.0 & 97.9 & 98.6 & 99.8 & 92.6 & 98.4 & 93.0 & 92.9 & 97.7 & 98.2 & 97.7 & 98.2 & 98.6 & 97.7 & 100 & $\ldots$ & $\ldots$ & $\ldots$ \\
\hline 16. CA IMI348494 & 93.3 & 98.9 & 100 & 98.4 & 93.3 & 99.8 & 93.3 & 93.1 & 98.6 & 99.7 & 98.6 & 99.6 & 100 & 98.6 & 98.6 & 100 & $\ldots$ & $\ldots$ \\
\hline 17. CA GL-118 & 92.8 & 99.8 & 98.6 & 97.6 & 92.9 & 98.4 & 92.8 & 92.7 & 99.5 & 98.1 & 99.5 & 99.1 & 98.6 & 99.5 & 97.9 & 98.6 & 100 & $\ldots$ \\
\hline 18. CA CECT & 93.0 & 99.8 & 98.6 & 97.5 & 93.0 & 98.4 & 93.0 & 92.9 & 99.6 & 98.2 & 99.6 & 99.1 & 98.6 & 99.6 & 97.7 & 98.6 & 99.6 & 100 \\
\hline
\end{tabular}

a Percent similarity, based on pairwise analysis of isolates, was calculated using the ARB software (University of Munich, Germany) (29). 
mation for the $C$. acutatum species by delineating the populations into additional groups and subgroups compared with ITS 1 region. This study has demonstrated considerable genetic variation between populations of $C$. acutatum, indicating that isolates within each subgroup are not host specific.

\section{ACKNOWLEDGMENTS}

This research was supported in part by Research Grant Award IS 282597 from BARD, The U.S.-Israel Binational Agricultural Research and Development Fund awarded to S. Freeman. We thank B. Teviotdale, University of California, Davis, for providing biological material from the United States and P. Cannon and A. Buddie, CABI Bioscience, Egham, England, for providing C. acutatum isolates (IMI345026 and IMI348494) from strawberry.

\section{LITERATURE CITED}

1. Adaskaveg, J. E., and Hartin, R. J. 1997. Characterization of Colletotrichum acutatum isolates causing anthracnose of almond and peach in California. Phytopathology 87:979-987.

2. Bailey, J. A., and Jeger, M. J. 1992. Colletotrichum: Biology, Pathology and Control. CAB International, Wallingford, U.K.

3. Bernstein, B., Zehr, E. I., Dean, R. A., and Shabi, E. 1995. Characteristics of Colletotrichum from peach, apple, pecan, and other hosts. Plant Dis. 79:478-482.

4. Brown, A. E., Sreenivasaprasad, S., and Timmer, L. W. 1996. Molecular characterization of slow-growing orange and Key lime anthracnose strains of Colletotrichum from citrus as C. acutatum. Phytopathology 86:523-527.

5. Buddie, A. G., Martínez-Culebras, P., Bridge, P. D., García, M. D., Querol, A., Cannon, P. F., and Monte, E. 1999. Molecular characterization of Colletotrichum strains derived from strawberry. Mycol. Res. 103:385-394.

6. Correll, J. C., Rhoads, D. D., and Guerber, J. C. 1994. Genetic and molecular diversity of populations of Glomerella cingulata, Colletotrichum gloeosporioides, and C. acutatum from apple fruit. Page 77 in: Int. Mycol. Congr., 5th.

7. Förster, H., and Adaskaveg, J. E. 1999. Identification of subpopulations of Colletotrichum acutatum and epidemiology of almond anthracnose in California. Phytopathology 89:1056-1065.

8. Freeman, S., and Katan, T. 1997. Identification of Colletotrichum species responsible for anthracnose and root necrosis of strawberry in Israel. Phytopathology 87:516-521.

9. Freeman, S., Katan, T., and Shabi, E. 1996. Characterization of Colletotrichum gloeosporioides isolates from avocado and almond fruits with molecular and pathogenicity tests. Appl. Environ. Microbiol. 62:10141020.

10. Freeman, S., Katan, T., and Shabi, E. 1998. Characterization of Colletotrichum species responsible for anthracnose diseases of various fruits. Plant Dis. 82:596-605.

11. Freeman, S., Minz, D., Jurkevitch, E., Maymon, M., and Shabi, E. 2000. Molecular analyses of Colletotrichum species from almond and other fruits. Phytopathology 90:608-614.

12. Freeman, S., Pham, M., and Rodriguez, R. J. 1993. Molecular genotyping of Colletotrichum species based on arbitrarily primed PCR, A+T-rich DNA, and nuclear DNA analyses. Exp. Mycol. 17:309-322.

13. Freeman, S., and Shabi, E. 1996. Cross-infection of subtropical and temperate fruits by Colletotrichum species from various hosts. Physiol. Mol. Plant Pathol. 49:395-404.

14. Freeman, S., Shabi, E., and Katan, T. 2000. Characterization of Colletotrichum acutatum causing anthracnose disease of anemone. Appl.
Environ. Microbiol. 66:5267-5272.

15. Grossman, L. I., and Hudspeth, M. E. S. 1985. Fungal mitochondrial genomes. Pages 65-103 in: Gene Manipulations in Fungi. J. W. Bennet and L. L. Lazure, eds. Academic Press, New York.

16. Guerber, J. C., and Correll, J. C. 1997. The first report of the teleomorph of Colletotrichum acutatum in the United States. Plant Dis. 81:1334.

17. Gupta, M., and Filner, P. 1991. Microsatellites amplify highly polymorphic DNA bands in SPAR of plant DNA. Page 1705 in: Proc. Int. Soc. Plant Mol. Biol., Tucson, AZ.

18. Johnston, P. R., and Jones, D. 1997. Relationships among Colletotrichum isolates from fruit-rots assessed using rDNA sequences. Mycologia 89:420-430.

19. Lardner, R., Johnston, P. R., Plummer, K. M., and Pearson, M. N. 1999. Morphological and molecular analysis of Colletotrichum acutatum sensu lato. Mycol. Res. 103:275-285.

20. Martín, M. P., and García-Figueres, F. 1999. Colletotrichum acutatum and C. gloeosporioides cause anthracnose in olives. Eur. J. Plant Pathol. 105:733-741.

21. Rodriguez, R. J., and Yoder, O. C. 1991. A family of conserved repetitive DNA elements from the fungal plant pathogen Glomerella cingulata (Colletotrichum lindemuthianum). Exp. Mycol. 15:232-242.

22. Sambrook, J., Fritsch, E. F., and Maniatis, T. 1989. Molecular Cloning: A Laboratory Manual. 2nd ed. Cold Spring Harbor Laboratory, Cold Spring Harbor, NY.

23. Sato, T., Ueda, S., Iijima, A., and Tezuka, N. 1996. Re-identification of pathogens of anemone and prune anthracnose. Ann. Phytopathol. Soc. Jpn. 62:170-174.

24. Sherriff, C., Whelan, M. J., Arnold, G. M., Lafay, J.-F., Brygoo, Y., and Bailey, J. A. 1994. Ribosomal DNA sequence analysis reveals new species groupings in the genus Colletotrichum. Exp. Mycol. 18:121-138.

25. Shi, Y., Correll, J. C., Guerber, J. C., and Rom, C. R. 1996. Frequency of Colletotrichum species causing bitter rot of apple in the southeastern United States. Plant Dis. 80:692-696.

26. Simmonds, J. H. 1965. A study of the species of Colletotrichum causing ripe fruit rots in Queensland. Qld. J. Agric. Sci. 22:437-459.

27. Sreenivasaprasad, S., Mills, P. R., and Brown, A. E. 1994. Nucleotide sequence of the rDNA spacer I enables identification of isolates of Colletotrichum as C. acutatum. Mycol. Res. 98:186-188.

28. Sreenivasaprasad, S., Mills, P. R., Meehan, B. M., and Brown, A. E. 1996. Phylogeny and systematics of 18 Colletotrichum species based on ribosomal DNA spacer sequences. Genome 39:499-512.

29. Strunk, O., Ludwig, W., Gross, O., Reichel, B., Stuckmann, N., May, M., Nonhoff, B., Lenke, M., Ginhart, T., Vilbig, A., and Westran, R. 1998. ARB-A software environment for sequence data. Technische Universität Munchen, Munich, Germany.

30. Sutton, B. C. 1992. The genus Glomerella and its anamorph Colletotrichum. Pages 1-26 in: Colletotrichum: Biology, Pathology and Control. J. A. Bailey and M. J. Jeger, eds. CAB International, Wallingford, U.K.

31. Tu, J. C. 1985. An improved Mathur's medium for growth, sporulation and germination of spores of Colletotrichum lindemuthianum. Microbiosis 44:87-93

32. Walker, J., Nikandrow, A., and Millar, G. D. 1991. Species of Colletotrichum on Xanthium (Asteraceae) with comments on some taxonomic and nomenclatural problems in Colletotrichum. Mycol. Res. 95:1175-1193.

33. Weising, K., Weigand, F., Driesel, A. J., Kahl, A. J., Zischer, H., and Epplen, J. T. 1989. Polymorphic simple GATA/GACA repeats in plant genomes. (Abstr.) Nucleic Acids Res. 17:10128.

34. White, T. J., Bruns, T., Lee, S., and Taylor, J. 1990. Amplification and direct sequencing of fungal ribosomal RNA genes for phylogenetics. Pages 315-322 in: PCR Protocols, A Guide to Methods and Applications. M. A. Innis, D. H. Gelfand, and J. J. Sninsky, eds. Academic Press, San Diego, CA. 